Review

\title{
Cytotoxic Natural Products from Marine Sponge-Derived Microorganisms
}

\author{
Huawei Zhang *, Ziping Zhao and Hong Wang \\ School of Pharmaceutical Sciences, Zhejiang University of Technology, Hangzhou 310014, China; \\ baix12012@163.com (Z.Z.); yingzhoudengyuan@sina.com (H.W.) \\ * Correspondence: hwzhang@zjut.edu.cn; Tel.: +86-571-8832-0903 \\ Academic Editor: Paul Long \\ Received: 13 December 2016; Accepted: 3 March 2017; Published: 10 March 2017
}

\begin{abstract}
A growing body of evidence indicates that marine sponge-derived microbes possess the potential ability to make prolific natural products with therapeutic effects. This review for the first time provides a comprehensive overview of new cytotoxic agents from these marine microbes over the last 62 years from 1955 to 2016, which are assorted into seven types: terpenes, alkaloids, peptides, aromatics, lactones, steroids, and miscellaneous compounds.
\end{abstract}

Keywords: marine microbe; sponge-derived microbe; natural product; cytotoxic compound

\section{Introduction}

The search for cytotoxic agents from marine resources has always attracted the attention of natural products chemists [1,2]. More than $10 \%$ of the screened marine sponges display cytotoxic activities [3-5]. Marine sponges are well known to be hosts for a large community of microorganisms, which comprise a significant percentage (up to $50 \%-60 \%$ ) of the biomass of the sponge host [6,7]. A growing body of evidence has indicated that marine sponges undergo symbiotic relationships with microbes such as bacteria and fungi, which are likely to be the prolific producers of bioactive secondary metabolites [8,9]. This review provides a comprehensive overview of 107 new cytotoxic agents metabolized by marine sponge-derived microbes, which are assorted into seven types, including terpenes, alkaloids, peptides, aromatics, lactones, steroids, and miscellaneous compounds discovered from 1955 to 2016.

\section{Terpenes}

\subsection{Sesquiterpenes}

Two new trichothecenes (Chart 1), 3-hydroxyroridin E (1) and 13'-acetyltrichoverrin B (2), were isolated from Myrothecium verrucaria associated with a Spongia sp. (Coll. No. 97103) collected from the coast of Maui, HI, USA, and were shown to have potent cytotoxicity against murine lymphocytic leukemia L1210 and human colon tumor H116 cell lines [10]. Chemical investigation of a marine-derived fungus Aspergillus ustus from the sponge Suberites domuncula (collected from the Adriatic Sea) led to isolation of two new drimane sesquiterpenoids 3 and 4 (Chart 1). Bioassay results indicated that these sesquiterpenes exhibited potent inhibitory effect on tumor cell lines L5178Y, HeLa, and PC12 with half maximal effective concentration $\left(\mathrm{EC}_{50}\right)$ values ranging from 0.6 to $5.3 \mu \mathrm{g} / \mathrm{mL}$ [11]. 


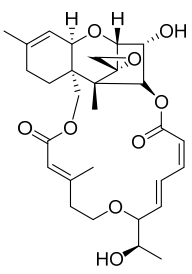

1

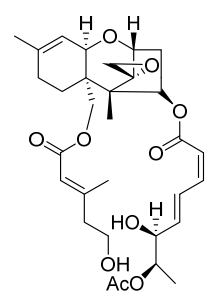

2

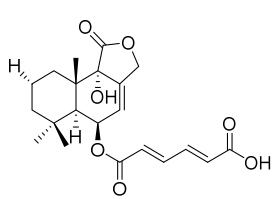

3

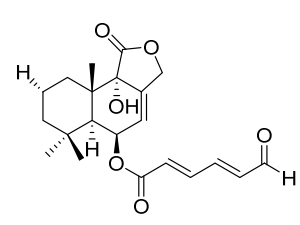

4

Chart 1. Chemical structures of compounds 1-4.

(E)-6-(40-hydroxy-20-butenoyl)-strobilactone A (5), isolated from Aspergillus insuetus (OY-207) colonizing in a Mediterranean sponge Psammocinia sp., was shown to have a cytotoxic effect on the MOLT- 4 cell line by $55 \%$ at $50 \mathrm{mg} / \mathrm{mL}$ [12]. Two new dimers of phenolic bisabolane sesquiterpenoid 6 and 7 (Chart 2) were metabolized by a marine-derived fungus Aspergillus sp. associated with the sponge Xestospongia testudinaria, which was collected around the South China Sea. Compound 6 exhibited in vitro moderate cytotoxicity against human hepatoma cell line HepG-2 and human cervical cell line Caski with half maximal inhibitory concentration $\left(\mathrm{IC}_{50}\right)$ values of 9.31 and $12.40 \mu \mathrm{g} / \mathrm{mL}$, while 7 showed selective activity with $\mathrm{IC}_{50}$ values of 2.91 and $10.20 \mu \mathrm{g} / \mathrm{mL}$, respectively [13].
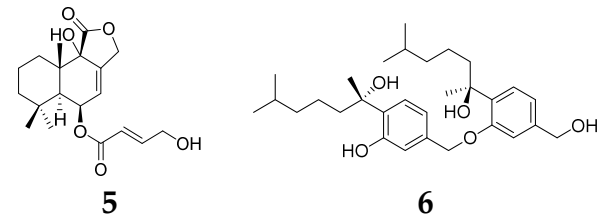

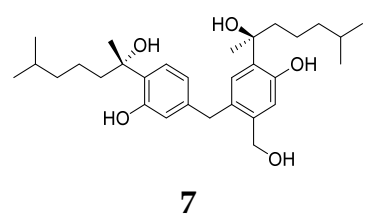

7

Chart 2. Chemical structures of compounds 5-7.

Four new bisabolane-type sesquiterpenoids (8-11) were found in the fermentation broth of Aspergillus sp. in the marine sponge Xestospongia testudinaria from the South China Sea (Chart 3). Biological assay suggested that these compounds were weakly cytotoxic $\left(\mathrm{IC}_{50}\right.$ value $>50 \mu \mathrm{g} / \mathrm{mL}$ ) against human promyelocytic leukemia HL-60 and human lung carcinoma A-549 [14]. The marine fungus Hansfordia sinuosae derived from the sponge Niphates sp., was shown to produce six new caryophyllene-based sesquiterpenoids, punctaporonins H-M (12-17) (Chart 3). However, these sesquiterpenoids possessed weak cytotoxicities against human colon carcinoma HCT-8, human hepatoma Bel7402, human gastric carcinoma BGC823, human lung adenocarcinoma A549, and human ovarian carcinoma A2780 with $\mathrm{IC}_{50}$ values $>10 \mu \mathrm{M}$ [15].

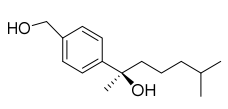

8

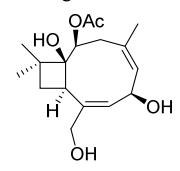

13

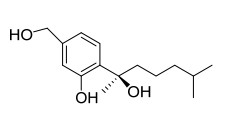

9

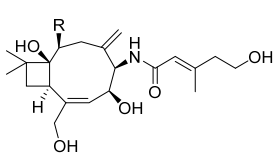

14: $\mathrm{R}=\mathrm{OAC}$

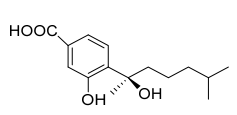

10

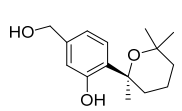

11

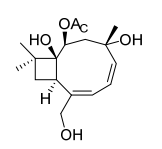

12

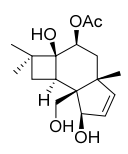

16

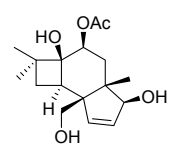

17

Chart 3. Chemical structures of compounds 8-17.

\subsection{Sesterterpenoids}

Chemical examination of the marine fungus Aspergillus ustus isolated from a Mediterranean sponge Suberites domuncula yielded five new ophiobolin-type sesterterpenoids 18-22 [16] (Chart 4). 
These compounds were assayed for their cytotoxic activity against the murine lymphoma cell line $\mathrm{L} 5178 \mathrm{Y}$ at $10 \mathrm{mg} / \mathrm{mL}$.

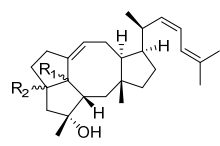

18: $\mathrm{R}_{1}=\mathrm{H}-\alpha, \mathrm{R}_{2}=\mathrm{OH}-\alpha$

19: $\mathrm{R}_{1}=\mathrm{H}-\alpha, \mathrm{R}_{2}=\mathrm{OMe}-\alpha$

20: $\mathrm{R}_{1}=\mathrm{H}-\beta, \mathrm{R}_{2}=\mathrm{OMe}-\beta$

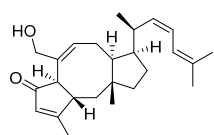

21

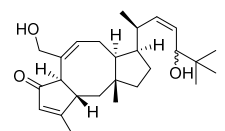

22

Chart 4. Chemical structures of compounds 18-22.

\subsection{Diterpenes}

Four novel decalin derivatives, tandyukisins (23-26), were produced by a strain of Trichoderma harzianum OUPS-111D-4 originally derived from the marine sponge Halichondria okadai collected in Osaka Bay, Japan (Chart 5). Cytotoxic assays suggest that compound 23 exhibited moderate cytotoxicity against murine leukemia cell lines P388 and L1210 and human leukemia cell line HL-60. Compounds $\mathbf{2 4 - 2 6}$ had moderate cytotoxicity against a disease-oriented panel of 39 human cancer cell lines (HCC panel). However, these diterpenes showed slightly selective growth inhibition against the central nervous system cancer SNB-75 cell line in the HCC panel $[17,18]$.

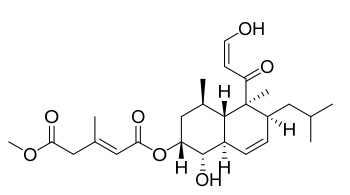

23

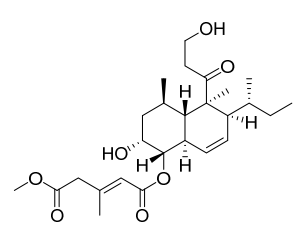

24

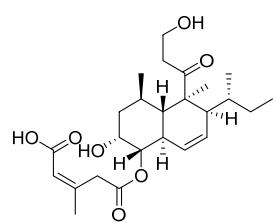

25

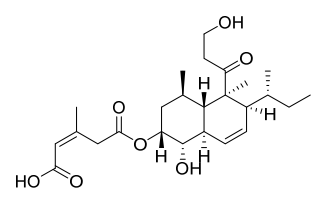

26

Chart 5. Chemical structures of compounds 23-26.

\subsection{Meroterpenoids}

Chemical investigation of the EtOAc extract of the culture medium of the marine-derived fungus Aspergillus insuetus OY-207 led to the isolation of a novel meroterpenoid, insuetolide C (27) (Chart 6). The strain OY-207 was isolated from a Mediterranean sponge Psammocinia sp. (collected approximately $200 \mathrm{~m}$ off-shore from Sdot-Yam, Israel). Compound 27 exhibited mild cytotoxicity towards human leukemia MOLT-4 cells [12]. Another Aspergillus strain derived from an unidentified sponge (collected at Manele Bay, HI, USA) was found to metabolize three new cytotoxic meroterpenoids, tropolactones A-C (28-30) (Chart 6), which showed weak cytotoxicity against human colon adenocarcinoma cells (HCT-116) with $\mathrm{IC}_{50}$ values of $13.2,10.9$ and $13.9 \mu \mathrm{M}$, respectively [19].

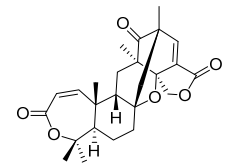

27

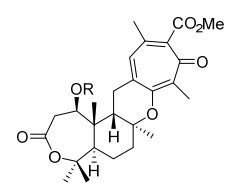

28: $\mathrm{R}=\mathrm{H}$

29: $\mathrm{R}=\mathrm{COCH}_{3}$

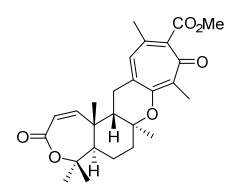

30

Chart 6. Chemical structures of compounds $27-30$.

\section{Alkaloids}

Chemical examination of the cultured mycelium of a bacterium Alteromonas sp. from the sponge Halichondria okadai led to the isolation of one novel tetracyclic alkaloid: 31 (Chart 7). It exhibited 
cytotoxicity against the murine leukemia cell line P388, murine lymphoma L1210, and human epidermoid carcinoma $\mathrm{KB}$ cells in vitro with $\mathrm{IC}_{50}$ values of $0.1,1.7$, and $5.0 \mu \mathrm{g} / \mathrm{mL}$, respectively [20]. $4^{\prime}$-N-methyl-5'-hydroxystaurosporine (32) and 5'-hydroxystaurosporine (33) (Chart 7) were obtained from a marine strain of Micromonospora sp. L-31-CLCO-002, a symbiont on the sponge Clathrina coriacea, and in vitro were shown to have strong cytotoxic activities against tumor cell lines P388D1 (ATCC CCL-46), A549 (ATCC CCL-185), HT-29 (ATCC HTB-38), and SK-MEL-28 (ATCC HTB-72) [21].

Two new congener alkaloids, communesins 34 and 35 (Chart 7), were detected in the ethyl acetate extract of a Penicillium sp. which was isolated from the Mediterranean sponge Axinella verrucosa. Communesin 34 was observed to be most active on the human acute $\mathrm{T}$ lymphoblastic leukemia cell line MOLT-3 with an $\mathrm{ED}_{50}$ value of $8.6 \mu \mathrm{g} / \mathrm{mL}$. Conversely, 35 possessed a strong inhibitory effect on the human acute B lymphoblastic leukemia cell line SUP-B15 with an $\mathrm{ED}_{50}$ value of $9.0 \mu \mathrm{g} / \mathrm{mL}$ [22]. A new sorbicillin-derived compound, 36, metabolized by Penicillium chrysogenum associated with the Mediterranean sponge Ircinia fasciculata was found to exhibit a strong cytotoxic activity against L5178y cells and low toxicity to cervical carcinoma HeLa S3 cells and pheochromocytoma PC12 cells [23]. Another Penicillium strain, P. aurantiogriseum SP0-19, was isolated from the marine sponge Mycale plumose and shown to produce two novel quinazoline alkaloids: aurantiomides $\mathbf{3 7}$ and $\mathbf{3 8}$. Compound 37 exhibited moderate cytotoxic activities against tumor cell lines HL-60 and P388 with $\mathrm{IC}_{50}$ values of 52 and $54 \mu \mathrm{g} / \mathrm{mL}$, respectively, while 38 selectively inhibited BEL-7402 and P388 cell lines with $\mathrm{IC}_{50}$ values of 62 and $48 \mu \mathrm{g} / \mathrm{mL}$, respectively [24].

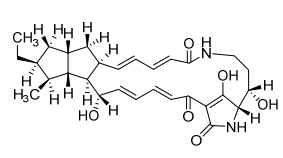

31

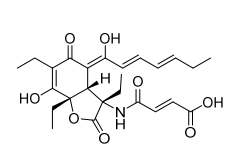

36

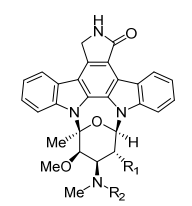

32: $\mathrm{R}_{1}=\mathrm{H}, \mathrm{R}_{2}=\mathrm{Me}$ 33: $\mathrm{R}_{1}=\mathrm{H}, \mathrm{R}_{2}=\mathrm{H}$

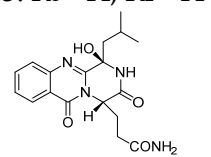

37

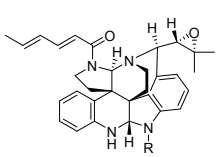

34: $\mathrm{R}=\mathrm{H}$

35: $\mathrm{R}=\mathrm{CHO}$

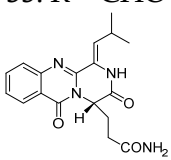

38

Chart 7. Chemical structures of compounds 31-38.

Chemical study of the marine-derived fungus Beauveria bassiana from the North Sea sponge Myxilla incrustans, afforded a new equisetin-like tetramic acid derivative beauversetin (39) with moderate activity against an unknown tumor cell line [25] (Chart 8). A novel indole oligomer (40) (Chart 8) was metabolized by a Psychrobacter strain isolated from the marine sponge Stelletta sp. (collected from the coast of Geoje Island) and was shown to have an inhibitory effect on five human solid tumor cell lines: A-549, SK-OV-3, SK-MEL-2, XF-498, and HCT-15 with EC 50 values of 2.34, 1.57, 3.44, 2.39, and $3.13 \mathrm{mg} / \mathrm{mL}$, respectively [26]. Three novel alkaloids, JBIR-46 (41), -47 (42), and -48 (43) (Chart 8), were detected in the cultures of bacterium Streptomyces setonensis SpC080624SC-11 and SpA080624GE-02, which were isolated from the marine sponge Cinachyra sp. and Stylotella aurantium (collected from the sea near Tateyama, Chiba Prefecture). Cytotoxic tests indicated that compounds 41-43 possessed weakly cytotoxic activities against human acute myelogenous leukemia HL-60 cells with $\mathrm{IC}_{50}$ values of 189, 226, and $96 \mu \mathrm{M}$, respectively [27]. Chemical examination of a marine fungus Aspergillus ustus, isolated from the Mediterranean sponge Suberites domuncula, yielded two new pyrrolidine alkaloids, 44 and 45 (Chart 8), which showed weak cytotoxicty against murine lymphoma L5178Y cells at $10 \mathrm{mg} / \mathrm{mL}[16]$. 


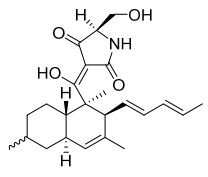

39

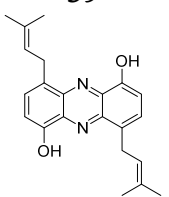

42

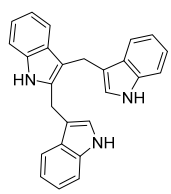

40

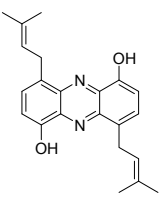

43

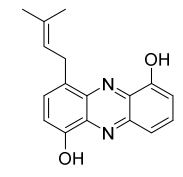

41

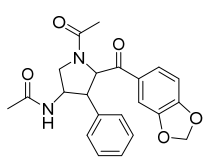

44: trans, trans-2,3,4-trisubstituted

45: cis, trans-2,3,4-trisubstituted

Chart 8. Chemical structures of compounds 39-45.

One new secondary metabolite, amycolactam (46) (Chart 9), was isolated from a rare actinomycete Amycolatopsis sp. colonized in an unidentified sponge gathered from Micronesia. It had a broad spectrum of cytotoxic activities against SNU638 and HCT116 with $\mathrm{IC}_{50}$ values of 0.8 and $2.0 \mu \mathrm{M}$, respectively, and against A546, K562, and SK-HEP1 cells with $\mathrm{IC}_{50}$ values of 13.7, 9.6, and $8.3 \mu \mathrm{M}$, respectively [28]. Ten novel cytotoxic compounds (47-56) (Chart 9) were produced by a strain of Gymnasella dankaliensis, a symbiont on a Homaxinella marine sponge (collected in the Osaka Bay of Japan). All these natural products exhibited cytotoxic activities against the lymphocytic leukemia P388 cell line (ED $\mathrm{E}_{50} 18.0,10.8,10.6,10.1,0.13,0.03,1.7,2.8,0.15$, and $0.16 \mu \mathrm{g} / \mathrm{mL}$, respectively). Furthermore, compound 53 had appreciable growth inhibition against tumor cell lines BSY-1 (breast) and MKN7 (stomach) lines (log $\mathrm{GI}_{50}$ : -5.47 and -5.17 , respectively) [29-32]. Continuous investigation of secondary metabolites produced by the Homaxinella derived fungus, Gymnascella dankaliensis, yielded a new compound dankastatin C (57) (Chart 9). This alkaloid exhibited an $\mathrm{ED}_{50}$ value of $57 \mathrm{ng} / \mathrm{mL}$ against the murine lymphocytic leukemia P388 cell line, which was as potent as that of 5-fluorouracil $\left(\mathrm{ED}_{50} 78 \mathrm{ng} / \mathrm{mL}\right)[33]$.

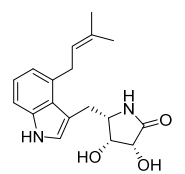

46

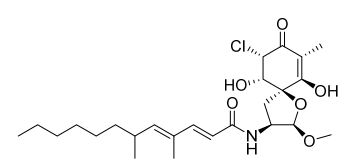

49

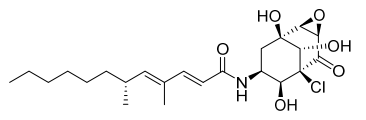

52

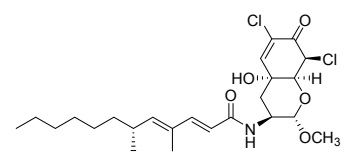

55

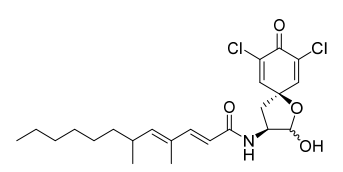

47

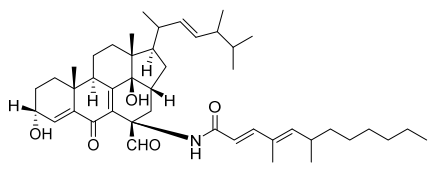

50

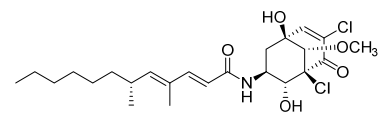

53

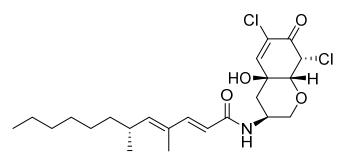

56

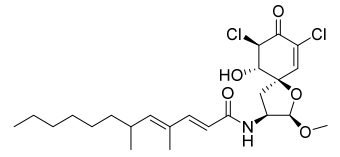

48

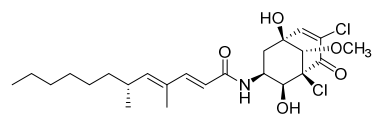

51

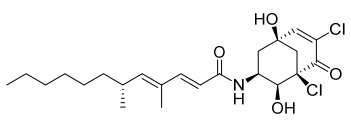

54

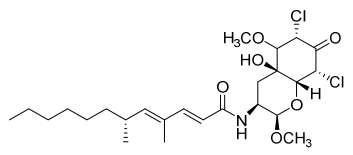

57

Chart 9. Chemical structures of compounds $46-57$. 


\section{Peptides}

Two highly N-methylated linear octapeptides, RHM1 (58) and RHM2 (59) (Chart 10), were produced by an atypical strain of Acremonium sp. cultured from a Teichaxinella sp. marine sponge (collected in Papua New Guinea) and were shown to have mild cytotoxicity against murine L1210 cells by a disk diffusion soft agar colony-forming assay [34]. The investigation of the chemical constituents of the mycelia and culture filtrate of a fungus Aspergillus versicolor from a marine sponge Petrosia sp. (collected off the coast of Jeju Island, Korea) yielded two novel lipopeptides: fellutamide $\mathrm{C}$ (60) and fellutamide F (61) (Chart 10). Compound 61 exhibited strong cytotoxiciy against human lung cancer A549, human ovarian cancer SK-OV-3, human skin cancer SK-MEL-2, human central nervous system (CNS) cancer XF498, and human colon cancer HCT15 [35,36]. One fungal strain, Aspergillus similanensis KUFA0013, derived from the sponge Rhabdermia sp. (Similan Islands, Thailand) was found to produce a new cyclohexapeptide, similanamide (62) (Chart 10), which possessed in vitro weak inhibitory activity against breast adenocarcinoma MCF-7, non-small cell lung cancer NCI-H460, and melanoma A373 cell lines [37]. Chemical examination of Scopulariopsis brevicaulis from the marine sponge Tethya aurantium (Limski Fjord, Croatia) afforded two novel cyclodepsipeptides: scopularides A (63) and B (64) (Chart 10). Bioassay tests suggested that compounds 63 and 64 significantly inhibited growth of three tumor cell lines. At a concentration of $10 \mu \mathrm{g} / \mathrm{mL}$, the viability of the cell lines Colo357, Panc89 (pancreatic tumor cells), and HT29 (colon tumor cells) was reduced by $36 \%$ (63) and 26\% (64), $42 \%(63)$ and $49 \%(64)$, and $37 \%(63)$ and $24 \%(64)$, respectively [38].

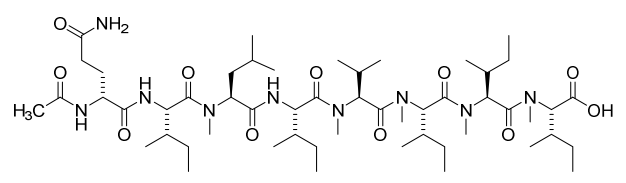

58

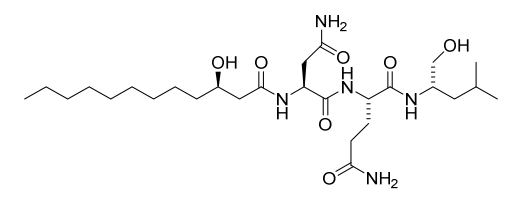

60

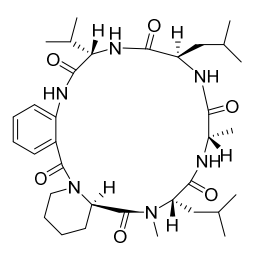

62

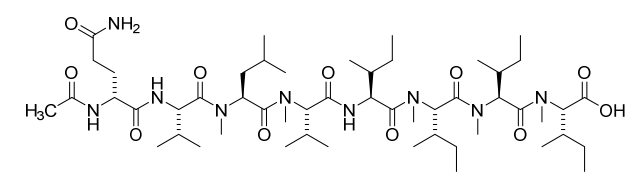

59

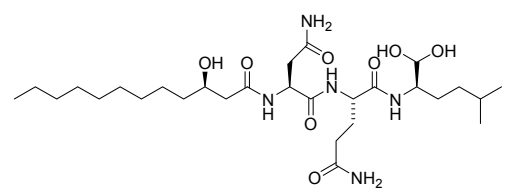

61

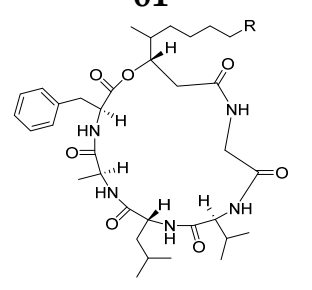

63: $\mathrm{R}=\mathrm{C}_{2} \mathrm{H}_{5}$

64: $\mathrm{R}=\mathrm{H}$

Chart 10. Chemical structures of compounds 58-64.

\section{Aromatics}

\subsection{Polyketides}

Chemical investigation of Penicillium brocae, obtained from a tissue sample of a Fijian sponge Zyzyya sp., led to the isolation of three novel polyketides: brocaenols A-C (65-67) (Chart 11). Compounds 65,66 and 67 showed moderate antiproliferative effects on the HCT-116 cell line with $\mathrm{IC}_{50}$ values of 20,50 , and $>50 \mu \mathrm{g} / \mathrm{mL}$, respectively [39]. 


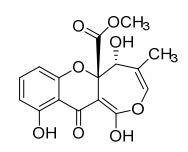

65

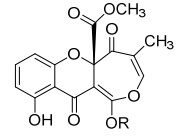

66: $\mathrm{R}=\mathrm{H}$

67: $\mathrm{R}=\mathrm{CH}_{3}$

Chart 11. Chemical structures of compounds 65-67.

\section{2. $\alpha$-Pyrone Derivatives}

Three new $\alpha$-pyrone derivatives (68-70) (Chart 12), were characterized from Petriella sp. associated with one Mediterranean sponge, Suberites domuncula. Compound 68 exhibited pronounced cytotoxic activity against the L5178Y cell line, while congeners 69 and 70 had moderate activity [40].

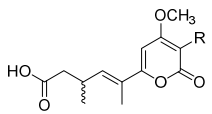

68: $\mathrm{R}=\mathrm{CH}_{3}$ 69: $\mathrm{R}=\mathrm{CH}_{2} \mathrm{OH}$<smiles>CC(C)CCCC(=O)O</smiles>

70

Chart 12. Chemical structures of compounds 68-70.

\subsection{Anthraquinones}

From a strain of the fungus Emericella variecolor derived from the marine sponge Haliclona valliculata (collected at Secca di Capo di Fonza, Elba, Italy), a new natural product called evariquinone $\mathbf{7 1}$ (Chart 13) was isolated and found to display antiproliferative activity towards tumor cell lines KB (60\% inhibition) and NCI-H460 (69\% inhibition) at $3.16 \mathrm{mg} / \mathrm{mL}$ [41]. Study on the bioactive metabolites of Aspergillus versicolor derived from a marine sponge Petrosia sp. (Jeju Island, Korea) afforded three anthraquinones (72-74) (Chart 13) by bioactivity-guided fractionation. Those metabolites exhibited significant cytotoxicity against five human solid tumor cell lines (A-549, SK-OV-3, SK-MEL-2, XF-498, and HCT-15) with $\mathrm{IC}_{50}$ values in the range of $0.41-3.88 \mu \mathrm{g} / \mathrm{mL}$ [42]. Three new compounds, JBIR-97 (75), -98 (76), and -99 (77) (Chart 13) were produced by a fungal strain Tritirachium sp., SpB081112MEf2, derived from the sponge Pseudoceratina purpure (collected from offshore sites in Sakuraguchi, Ishigaki Island, Okinawa Prefecture, Japan). By the water-soluble tetrazolium-8 (WST-8) colorimetric assay, compounds 75, 76, and 77 were shown to have cytotoxic effects on HeLa cells $\left(\mathrm{IC}_{50}: 11,17\right.$, and $17 \mu \mathrm{M}$, respectively) and ACC-MESO-1 cells ( $\mathrm{IC}_{50}$ : 31, 63, and $59 \mu \mathrm{M}$, respectively) [43].
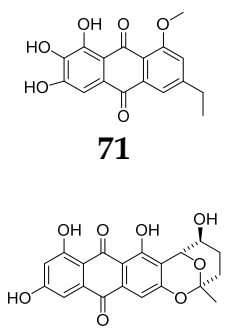

74

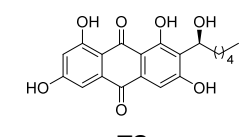

72

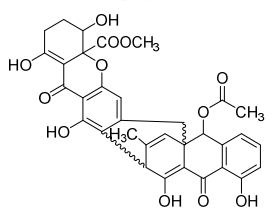

75 and 76

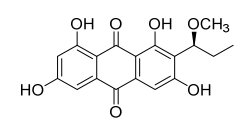

73

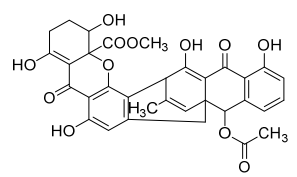

77

Chart 13. Chemical structures of compounds 71-77.

\subsection{Bicoumarin}

Fractionation of the EtOAc extract of a static culture of Aspergillus niger from a Mediterranean sponge Axinella damicornis, yielded one new secondary metabolite: $3,3^{\prime}$-bicoumarin bicoumanigrin 
(78) (Chart 14). MTT assay indicated that this compound exhibited moderate inhibitory effects on the growth of leukemia and carcinoma cell lines using incorporation of ${ }^{3} \mathrm{H}$-thymidine as a marker [44].

\subsection{Ethers}

Two new prenylated diphenyl ethers (79 and 80) (Chart 14) were purified from the fungus strain of Aspergillus versicolor Hmp-F48 associated with marine sponge Hymeniacidon perleve. Compounds 79 and $\mathbf{8 0}$ showed moderate inhibitory activities against the human promyelocytic leukemia cell line HL-60 with IC $_{50}$ values of 6.35 and $19.97 \mu \mathrm{M}$, respectively [45].

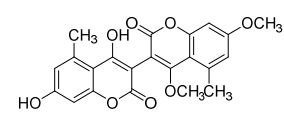

78

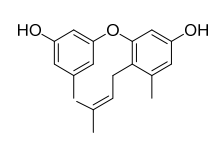

79

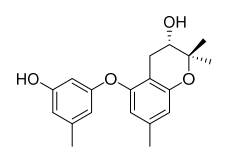

80

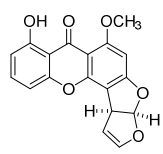

81

Chart 14. Chemical structures of compounds 78-81.

\subsection{Xanthones}

Chemical analysis of the fungal strain Aspergillus versicolor derived from a marine sponge Petrosia sp. (collected from the coast of Jeju Island, Korea), afforded a new xanthone $\mathbf{8 1}$ (Chart 14), which had strong cytotoxic activity against five human tumor cell lines (A-549, SK-OV-3,SK-MEL-2, XF-498, and HCT-15) with $\mathrm{IC}_{50}$ values ranging from 1.22 to $4.61 \mu \mathrm{g} / \mathrm{mL}$ [42].

\subsection{Other Aromatic Compounds}

One new aromatic compound, (S)-2,4-dihydroxy-1-butyl-(4-hydroxy) benzoate (82) (Chart 15), was characterized from Penicillium auratiogriseum associated with the marine sponge Mycale plumose (Qingdao, China). This metabolite was shown to exhibit potent cytotoxic effect on tsFT210 cells with an MIC (minimum inhibitory concentration) value of $8.0 \mu \mathrm{g} / \mathrm{mL}$ [46]. Fractionation of the extract of a fermentation broth of a marine sponge-derived strain of Streptomyces sp., SpD081030ME-02 (collected at offshore of Ishigaki City, Japan) afforded a new compound JBIR-58 (83) (Chart 15), exhibited cytotoxic effect on HeLa cells with an $\mathrm{IC}_{50}$ value of $28 \mu \mathrm{M}$ [47]. A new anthracycline, tetracenoquinocin (84) (Chart 15), was metabolized by the Streptomyces sp. Sp080513GE-26 associated with Haliclona sp. (Tateyama City, Japan) and showed weaker cytotoxicity against human cervical carcinoma HeLa cells and acute myelogenous leukemia LH-60 cells with $\mathrm{IC}_{50}$ values of 120 and $210 \mu \mathrm{M}$, respectively [48]. From a Porifera sponge-derived strain, Emericella variecolor, one new aromatic varitriol (85) (Chart 15) was identified and found to have a broad spectrum of anti-proliferative effects [49]. The new dibenzo(1,4)dioxin $\mathbf{8 6}$ (Chart 15) was isolated from Aspergillus versicolor Hmp-F48, associated with marine sponge Hymeniacidon perleve, and exhibited moderate inhibitory activity against HL-60 cells with $\mathrm{IC}_{50} 3.62 \mu \mathrm{M}$ [45].

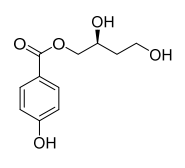

82

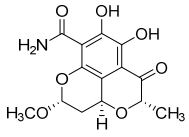

83

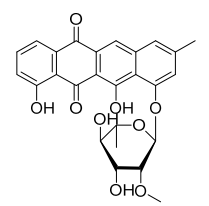

84

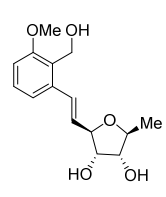

85

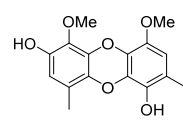

86

Chart 15. Chemical structures of compounds 82-86.

\section{Lactones}

Chemical analysis of Emericella variecolor XSA-07-2 isolated from the South China Sea sponge Cinachyrella sp. afforded four new lactones varioxiranols I-L (87-90) (Chart 16) with different scaffolds. 
Cytotoxic tests suggested that these isolates showed moderate cytotoxic activities against human colon carcinoma (HCT-116), liver hepatocellular carcinoma (HepG2), gastric cancer (BGC-823), lung cancer stem cells (NCI-H1650), and human ovarian cancer (A2780) [50]. One bacterial strain, Streptomyces carnosus, obtained from marine sponges Hymeniacidon sp. (collected from coastal waters of East China) was found to produce two new lactones: lobophorin C (91) and D (92) (Chart 16). Compound 91 displayed potent cytotoxic activity against the cell proliferation of hepatoma 7402 with an $\mathrm{IC}_{50}$ value of $0.6 \mu \mathrm{g} / \mathrm{mL}$. In addition, 92 had a strong inhibitory effect on the growth of the human breast cancer cell line MDA-MB 435 with IC $_{50} 7.5 \mu \mathrm{M}$ [51]. Three new benzolactones, chrysoarticulins A-C (93-95) (Chart 16), were isolated from the culture broth of Chrysosporium articulatum collected from an unidentified dictyoceratid sponge (Gagu-do, Korea). All these compounds exhibited weak cytotoxicity against tumor cell lines K562 and A549 [52].

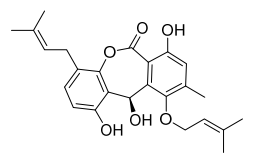

87

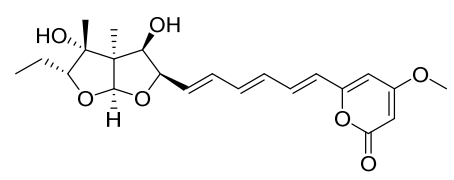

90

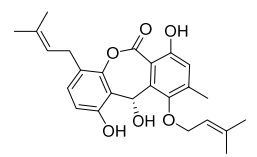

88

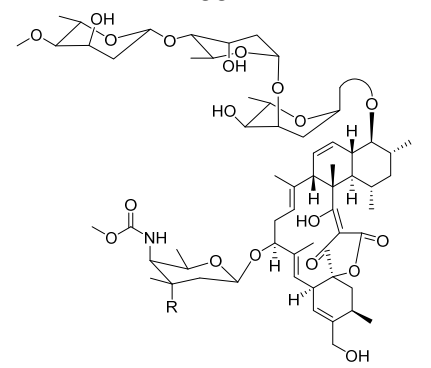

91: $\mathrm{R}=\mathrm{NO}_{2}$

92: $\mathrm{R}=\mathrm{NH}_{2}$

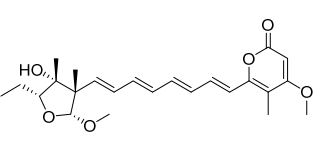

89
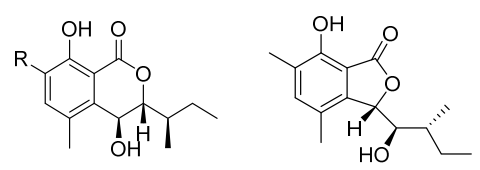

93: $\mathrm{R}=\mathrm{CH}_{3}$ 94: $\mathrm{R}=\mathrm{CH}_{2} \mathrm{OH}$
95

Chart 16. Chemical structures of compounds 87-95.

\section{Steroids}

Five structurally unusual steroids, 96, 97, 98, 99, and 100 (Chart 17), were metabolized by one marine strain of Gymnasella dankaliensis isolated from the sponge Halichondria japonica (Osaka Bay, Japan) and exhibited significant and marginal growth inhibition against the lymphocytic leukemia P388 cell line with $\mathrm{ED}_{50}$ values of 1.6, 2.2, 2.8, 0.9, and $2.5 \mu \mathrm{g} / \mathrm{mL}$, respectively [29,53,54].

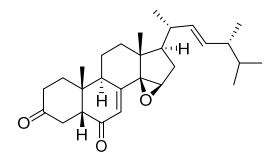

96

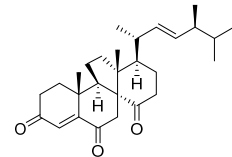

97

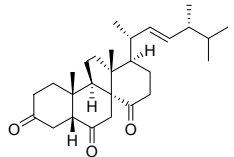

98

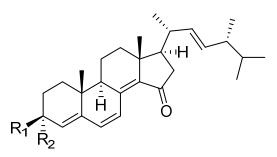

99: $\mathrm{R}_{1}=\mathrm{OH}, \mathrm{R}_{2}=\mathrm{H}$

100: $R_{1}, R_{2}=O$

Chart 17. Chemical structures of compounds 96-100.

\section{Miscellaneous Compounds}

Novel metabolites trichodenones A-C (101-103) (Chart 18) were detected in the culture broth of Trichoderma harzianum OUPS-N 115 originally separated from marine sponge Halichondria okadai (collected in the Tanabe Bay, Japan) and shown to possess strong cytotoxicity against P388 cells [55]. Chemical investigation of the fungal strain Penicillium citrinum SpI080624G1f01, derived from the Demospongiae sponge (collected from Ishigaki Island, Japan), afforded a new compound, JBIR-59 (104) (Chart 18), which had L-glutamate toxicity against tumor cell line N18-RE-105 with an $\mathrm{EC}_{50}$ value 
of $71 \mu \mathrm{M}$ [56]. One novel sterol bendigole 105 (Chart 18) produced by Actinomadura sp. SBMs009 from the marine sponge Suberites japonicus displayed a moderate cytotoxic effect on the L929 cells with an $\mathrm{IC}_{50}$ value of $30 \mu \mathrm{M}$ [57]. Two new structurally unique compounds bearing a nitrogen and sulfur-containing tricyclic ring system, ulbactin F (106) and its diastereomeric isomer ulbactin G (107) (Chart 18), were isolated from the culture extract of Brevibacillus sp. associated with an unidentified marine sponge (Iwate, Japan). Bioassay testing indicated that 106 and $\mathbf{1 0 7}$ had a strong inhibitory effect on epidermoid carcinoma cell line A431 at non-cytotoxic concentrations with $\mathrm{IC}_{50}$ values of 6.4 and $6.1 \mu \mathrm{M}$, respectively [58].

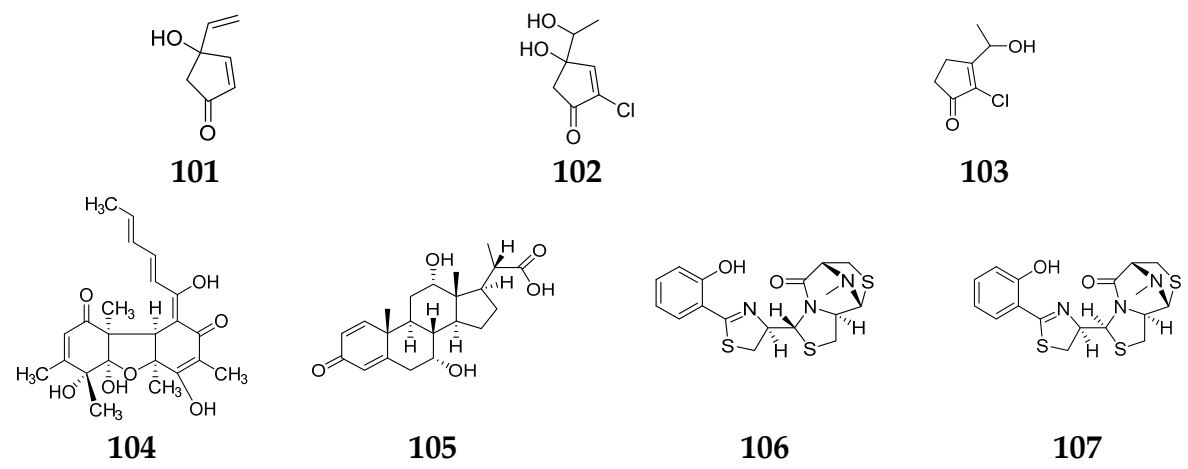

Chart 18. Chemical structures of compounds 101-107.

In summary, microorganisms associated with marine sponges are a prolific source of novel cytotoxic natural products with rich chemical structures. The utilization of natural products as sources of new drugs is still alive and well, especially in the area of cancer [59]. Generally, any cytotoxic chemical with an $\mathrm{IC}_{50}$ or $\mathrm{ED}_{50}$ value $<1 \mu \mathrm{M}$ has great potential for application in the discovery of new anti-tumor drugs/leads, for example, tetracyclic alkaloid 31 and dankastatin C (57). These candidates may play an important role in defeating human cancer.

Acknowledgments: This project was co-financed by grands for H.Z. and H.W. from the Zhejiang Natural Science Foundation of China (LY16H300007 and LY16H300008).

Author Contributions: H.Z. conceived and wrote the review; Z.Z. searched and collected the references; H.W. provided an effective analysis of the document.

Conflicts of Interest: The authors declare no conflict of interest.

\section{References}

1. Bhanot, A.; Sharma, R.; Noolvi, M.N. Natural sources as potential anti-cancer agents: A review. Int. J. Phytomed. 2011, 3, 9-26.

2. Zheng, L.; Yan, X.J.; Han, X.T.; Chen, H.M.; Lin, W.; Lee, F.S.C.; Wang, X.R. Identification of norharman as the cytotoxic compound produced by the sponge (Hymeniacidon perleve)-associated marine bacterium Pseudoalteromonas piscicida and its apoptotic effect on cancer cells. Biotechnol. Appl. Biochem. 2006, 44, 135-142. [PubMed]

3. Zhang, W.; Zhang, X.; Cao, X.; Xu, J.; Zhao, Q.; Yu, X.; Jin, M.; Deng, M. Optimizing the formation of in vitro sponge primmorphs from the Chinese sponge Stylotella agminata (Ridley). J. Biotechnol. 2003, 100, 161-168. [CrossRef]

4. Belarbi, E.; Gomez, A.C.; Chisti, Y.; Camacho, F.G.; Grima, E.M. Producing drugs from marine sponges. Biotechnol. Adv. 2003, 21, 585-598. [CrossRef]

5. Dembitsky, V.M.; Gloriozova, T.A.; Poroikov, V.V. Novel antitumor agents: Marine sponge alkaloids, their synthetic analogs and derivatives. Mini Rev. Med. Chem. 2005, 5, 319-336. [CrossRef] [PubMed]

6. Bergmann, W.B.; Burke, D.C. Contributions to the study of marineproducts. XXXIX. The nucleosides of sponges. III. Spongothymidine and spongouridine. J. Org. Chem. 1955, 20, 1501-1507. [CrossRef] 
7. Wang, G. Diversity and biotechnological potential of the sponge-associated microbial consortia. J. Ind. Microbiol. Biotechnol. 2006, 33, 545-551. [CrossRef] [PubMed]

8. Thomas, T.; Rusch, D.; DeMaere, M.Z.; Yung, P.Y.; Lewis, M.; Halpern, A.; Heidelberg, K.B.; Egan, S.; Steinberg, P.D.; Kjelleberg, S. Functional genomic signatures of sponge bacteria reveal unique and shared features of symbiosis. ISME J. 2010, 4, 1557-1567. [CrossRef] [PubMed]

9. Richelle-Maurer, E.G.; Gomez, R.; Braekman, J.C.; van de Vyver, G.; van Soest, R.W.; Devijver, C. Primary cultures from the marine sponge Xestospongia muta (petrosiidae, haplosclerida). J. Biotechnol. 2003, 100, 169-176. [CrossRef]

10. Amagata, T.; Rath, C.; Rigot, J.F.; Tarlov, N.; Tenney, K.; Valeriote, F.A.; Crews, P. Structures and cytotoxic properties of trichoverroids and their macrolide analogues produced by saltwater culture of Myrothecium verrucaria. J. Med. Chem. 2003, 46, 4342-4350. [CrossRef] [PubMed]

11. Liu, H.; Edrada-Ebel, R.; Ebel, R.; Wang, Y.; Schulz, B.; Draeger, S.; Müller, W.E.G.; Wray, V.; Lin, W.; Proksch, P. Drimane sesquiterpenoids from the fungus Aspergillus ustus isolated from the marine sponge Suberites domuncula. J. Nat. Prod. 2009, 72, 1585-1588. [CrossRef] [PubMed]

12. Cohen, E.; Koch, L.; Thu, K.M.; Rahamim, Y.; Aluma, Y.; Ilan, M.; Yarden, O.; Carmeli, S. Novel terpenoids of the fungus Aspergillus insuetus isolated from the Mediterranean sponge Psammocinia sp. collected along the coast of Israel. Bioorg. Med. Chem. Lett. 2011, 19, 6587-6593. [CrossRef] [PubMed]

13. Sun, L.L.; Shao, C.L.; Chen, J.F.; Guo, Z.Y.; Fu, X.M.; Chen, M.; Chen, Y.Y.; Li, R.; de Voogd, N.J.; She, Z.G.; et al. New bisabolane sesquiterpenoids from a marine-derived fungus Aspergillus sp. isolated from the sponge Xestospongia testudinaria. Bioorg. Med. Chem. Lett. 2012, 22, 1326-1329. [CrossRef] [PubMed]

14. Li, D.; Xu, Y.; Shao, C.L.; Yang, R.Y.; Zheng, C.J.; Chen, Y.Y.; Fu, X.M.; Qian, P.Y.; She, Z.G.; de Voogd, N.J.; et al. Antibacterial bisabolane-type sesquiterpenoids from the sponge-derived fungus Aspergillus sp. Mar. Drugs 2012, 10, 234-241. [CrossRef] [PubMed]

15. Wu, Z.; Liu, D.; Proksch, P.; Guo, P.; Lin, W. Punctaporonins H-M: Caryophyllene-type sesquiterpenoids from the sponge-associated fungus Hansfordia sinuosae. Mar. Drugs 2014, 12, 3904-3916. [CrossRef] [PubMed]

16. Liu, H.B.; Edrada-Ebel, R.; Ebel, R.; Wang, Y.; Schulz, B.; Draeger, S.; Müller, W.E.G.; Wray, V.; Lin, W.H.; Proksch, P. Ophiobolin sesterterpenoids and pyrrolidine alkaloids from the sponge derived fungus Aspergillus ustus. Helv. Chim. Acta 2011, 94, 623-631. [CrossRef]

17. Yamada, T.; Mizutani, Y.; Umebayashi, Y.; Inno, N.; Kawashima, M.; Kikuchi, T.; Tanaka, R. Tandyukisin, a novel ketoaldehyde decalin derivative, produced by a marine sponge-derived Trichoderma harzianum. Tetrahedron Lett. 2014, 55, 662-664. [CrossRef]

18. Yamada, T.; Umebayashi, Y.; Kawashima, M.; Sugiura, Y.; Kikuchi, T.; Tanaka, R. Determination of the chemical structures of tandyukisins B-D, isolated from a marine sponge-derived fungus. Mar. Drugs 2015, 13, 3231-3240. [CrossRef] [PubMed]

19. Cueto, M.; MacMillan, J.B.; Jensen, P.R.; Fenical, W. Tropolactones A-D, four meroterpenoids from a marine-derived fungus of the genus Aspergillus. Phytochemistry 2006, 67, 1826-1831. [CrossRef] [PubMed]

20. Shigemori, H.; Bae, M.A.; Yazawa, K.; Sasaki, T.; Kobayashi, J. Alteramide A, a new tetracyclic alkaloid from a bacterium Alteromonas sp. associated with the marine sponge Ealhhondria okadai. J. Org. Chem. 1992, 57, 4317-4320. [CrossRef]

21. Hernández, L.M.; Blanco, J.A.; Baz, J.P.; Puentes, J.L.; Millán, F.R.; Vázquez, F.E.; Fernández-Chimeno, R.I.; Grávalos, D.G. 4'-N-methyl-5'-hydroxystaurosporine and 5'-hydroxystaurosporine, new indolocarbazole alkaloids from a marine Micromonospora sp. strain. J. Antibiot. 2000, 53, 895-902. [CrossRef] [PubMed]

22. Jadulco, R.; Edrada, R.A.; Ebel, R.; Berg, A.; Schaumann, K.; Wray, V.; Steube, K.; Proksch, P. New communesin derivatives from the fungus Penicillium sp. derived from the Mediterranean sponge Axinella verrucosa. J. Nat. Prod. 2004, 67, 78-81. [CrossRef] [PubMed]

23. Bringmann, G.; Lang, G.; Gulder, T.A.M.; Tsuruta, H.; Mühlbacher, J.; Maksimenka, K.; Steffens, S.; Schaumann, K.; Stöhr, R.; Wiese, J.; et al. The first sorbicillinoid alkaloids, the antileukemic sorbicillactones A and B, from a sponge-derived Penicillium chrysogenum strain. Tetrahedron 2005, 61, 7252-7265. [CrossRef]

24. Xin, Z.H.; Fang, Y.; Du, L.; Zhu, T.; Duan, L.; Chen, J.; Gu, Q.Q.; Zhu, W.M. Aurantiomides A-C, quinazoline alkaloids from the sponge-derived fungus Penicillium aurantiogriseum SP0-19. J. Nat. Prod. 2007, 70, 853-855. [CrossRef] [PubMed]

25. Neumann, K.; Kehraus, S.; Gütschowb, M.; König, G.M. Cytotoxic and HLE-inhibitory tetramic acid derivatives from marine-derived fungi. Nat. Prod. Commun. 2009, 4, 347-354. [PubMed] 
26. Li, H.; Li, J.; Lee, C.O.; Bae, K.S.; Hong, J.; Jung, J.H. Indole oligomers from a marine sponge-associated bacterium Psychrobacter sp. Biochem. Syst. Ecol. 2010, 38, 839-841. [CrossRef]

27. Khan, S.T.; Izumikawa, M.; Motohashi, K.; Mukai, A.; Takagi, M.; Shin-Ya, K. Distribution of the 3-hydroxyl-3-methylglutaryl coenzyme A reductase gene and isoprenoid production in marine-derived Actinobacteria. FEMS Microbiol. Lett. 2010, 304, 89-96. [CrossRef] [PubMed]

28. Kwon, Y.; Kim, S.H.; Shin, Y.; Bae, M.; Kim, B.Y.; Lee, S.K.; Oh, K.B.; Shin, J.; Oh, D.C. A new benzofuran glycoside and indole alkaloids from a sponge-associated rare actinomycete, Amycolatopsis sp. Mar. Drugs 2014, 12, 2326-2340. [CrossRef] [PubMed]

29. Amagata, T.; Minoura, K.; Numata, A. Gymnasterones, novel cytotoxic metabolites produced by a fungal strain from a sponge. Tetrahedron Lett. 1998, 39, 3773-3774. [CrossRef]

30. Numata, A.; Amagata, T.; Minoura, K.; Ito, T. Gymnastatins, novel cytotoxic metabolites produced by a fungal strain from a sponge. Tetrahedron Lett. 1997, 38, 5675-5678. [CrossRef]

31. Amagata, T.; Minoura, K.; Numata, A. Gymnastatins F-H, cytostatic metabolites from the sponge-derived fungus Gymnascella dankaliensis. J. Nat. Prod. 2006, 69, 1384-1388. [CrossRef] [PubMed]

32. Amagata, T.; Tanaka, M.; Yamada, T.; Minoura, K.; Numata, A. Gymnastatins and Dankastatins, growth inhibitory metabolites of a Gymnascella species from a Halichondria sponge. J. Nat. Prod. 2008, 71, 340-345. [CrossRef] [PubMed]

33. Amagata, T.; Tanaka, M.; Yamada, T.; Chen, Y.P.; Minoura, K.; Numata, A. Additional cytotoxic substances isolated from the sponge-derived Gymnascella dankaliensis. Tetrahedron Lett. 2013, 54, 5960-5962. [CrossRef]

34. Boot, C.M.; Tenney, K.; Valeriote, F.A.; Crews, P. Highly N-methylated linear peptides produced by an atypical sponge-derived Acremonium sp. J. Nat. Prod. 2006, 69, 83-92. [CrossRef] [PubMed]

35. Lee, Y.M.; Dang, H.T.; Hong, J.K.; Lee, C.O.; Bae, K.S.; Kim, D.K.; Jung, J.H. A cytotoxic lipopeptide from the sponge-derived fungus Aspergillus versicolor. Bull. Korean Chem. Soc. 2010, 31, 205-208. [CrossRef]

36. Lee, Y.M.; Dang, H.T.; Li, J.; Zhang, P.; Hong, J.K.; Lee, C.O.; Jung, J.H. A cytotoxic fellutamide analogue from the sponge-derived fungus Aspergillus versicolor. Bull. Korean Chem. Soc. 2011, 32, 3817-3820. [CrossRef]

37. Prompanya, C.; Fernandes, C.; Cravo, S.; Pinto, M.; Dethoup, T.; Silva, A.; Kijjoa, A. A new cyclic hexapeptide and a new isocoumarin derivative from the marine sponge-associated fungus Aspergillus similanensis KUFA 0013. Mar. Drugs 2015, 13, 1432-1450. [CrossRef] [PubMed]

38. Yu, Z.; Lang, G.; Kajahn, I.; Schmaljohann, R.; Imhoff, J.F. Scopularides A and B, cyclodepsipeptides from a marine sponge-derived fungus, Scopulariopsis brevicaulis. J. Nat. Prod. 2008, 71, 1052-1054. [CrossRef] [PubMed]

39. Bugni, T.S.; Bernan, V.S.; Greenstein, M.; Janso, J.E.; Maiese, W.M.; Mayne, C.L.; Ireland, C.M. Brocaenols A-C: Novel polyketides from a marine-derived Penicillium brocae. J. Org. Chem. 2003, 68, 2014-2017. [CrossRef] [PubMed]

40. Ebel, R.; Riebe, F.; Proksch, P.; Schulz, B.; Müller, W. New cytotoxic $\alpha$-pyrone derivatives from the sponge-derived fungus Petriella sp. Planta Med. 2007, 73, 9. [CrossRef]

41. Bringmann, G.; Lang, G.; Steffens, S.; Günther, E.; Schaumann, K. Evariquinone, isoemericellin, and stromemycin from a sponge derived strain of the fungus Emericella variecolor. Phytochemistry 2003, 63, 437-443. [CrossRef]

42. Lee, Y.M.; Li, H.; Hong, J.; Cho, H.Y.; Bae, K.S.; Kim, M.A.; Kim, D.K.; Jung, J.H. Bioactive metabolites from the sponge-derived fungus Aspergillus versicolor. Arch. Pharmacol. Res. 2010, 33, 231-235. [CrossRef] [PubMed]

43. Ueda, J.Y.; Takagi, M.; Shin-ya, K. New xanthoquinodin-like compounds, JBIR-97, -98 and -99, obtained from marine sponge-derived fungus Tritirachium sp. SpB081112MEf2. J. Antibiot. 2010, 63, 615-618. [CrossRef] [PubMed]

44. Hiort, J.; Maksimenka, K.; Reichert, M.; Perovic'-Ottstadt, S.; Lin, W.H.; Wray, V.; Steube, K.; Schaumann, K.; Weber, H.; Proksch, P.; et al. New natural products from the sponge-derived fungus Aspergillus niger. J. Nat. Prod. 2004, 67, 1532-1543. [CrossRef] [PubMed]

45. Wang, X.; Mou, Y.; Hu, J.; Wang, N.; Zhao, L.; Liu, L.; Wang, S.; Meng, D. Cytotoxic polyphenols from a sponge-associated fungus Aspergillus versicolor Hmp-48. Chem. Biodivers. 2014, 11, 133-139. [CrossRef] [PubMed] 
46. Xin, Z.H.; Zhu, W.M.; Gu, Q.Q.; Fang, Y.C.; Duan, L.; Cui, C.B. A new cytotoxic compound from Penicillium auratiogriseum symbiotic or epiphytic fungus of sponge Mycale plumose. Chin. Chem. Lett. 2005, 16, 1227-1229.

47. Ueda, J.Y.; Khan, S.T.; Takagi, M.; Shin-ya, K. JBIR-58, a new salicylamide derivative, isolated from a marine sponge-derived Streptomyces sp. SpD081030ME-02. J. Antibiot. 2010, 63, 267-269. [CrossRef] [PubMed]

48. Motohashi, K.; Takagi, M.; Shin-ya, K. Tetracenoquinocin and 5-iminoaranciamycin from a sponge-derived Streptomyces sp. Sp080513GE-26. J. Nat. Prod. 2010, 73, 755-758. [CrossRef] [PubMed]

49. Malmstrøm, J.; Christophersen, C.; Barrero, A.F.; Oltra, J.E.; Justicia, J.; Rosales, A. Bioactive metabolites from a marine-derived strain of the fungus Emericella. J. Nat. Prod. 2002, 65, 364-367. [CrossRef] [PubMed]

50. Wu, Q.; Long, H.L.; Liu, D.; Proksch, P.; Lin, W.H. Varioxiranols I-L, new lactones from a sponge-associated Emericella variecolor fungus. J. Asian Nat. Prod. Res. 2015, 17, 1137-1145. [CrossRef] [PubMed]

51. Wei, R.B.; Xi, T.; Li, J.; Wang, P.; Li, F.C.; Lin, Y.C.; Qin, S. Lobophorin C and D, new kijanimicin derivatives from a marine sponge-associated actinomycetal strain AZS17. Mar. Drugs 2011, 9, 359-368. [CrossRef] [PubMed]

52. Jeon, J.E.; Julianti, E.; Oh, H.; Park, W.; Oh, D.C.; Oh, K.B.; Shin, J. Stereochemistry of hydroxy-bearing benzolactones: Isolation and structural determination of chrysoarticulins A-C from a marine-derived fungus Chrysosporium articulatum. Tetrahedron Lett. 2013, 54, 3111-3115. [CrossRef]

53. Amagata, T.; Doi, M.; Tohgo, M.; Minoura, K.; Numata, A. Dankasterone, a new class of cytotoxic steroid produced by a Gymnascella species from a marine sponge. Chem. Commun. 1999, 14, 1321-1322. [CrossRef]

54. Amagata, T.; Tanaka, M.; Yamada, T.; Doi, M.; Minoura, K.; Ohishi, H.; Yamori, T.; Numata, A.; Makhloufi, G. Variation in cytostatic constituents of a sponge-derived Gymnascella dankaliensis by manipulating the carbon source. J. Nat. Prod. 2007, 70, 1731-1740. [CrossRef] [PubMed]

55. Amagata, T.; Usami, Y.; Minoura, K.; Ito, T.; Numata, A. Cytotoxic substances produced by a fungal strain from a sponge: Physico-chemical properties and structures. J. Antibiot. 1998, 51, 33-40. [CrossRef] [PubMed]

56. Ueda, J.Y.; Hashimoto, J.; Inaba, S.; Takagi, M.; Shin-ya, K. JBIR-59, a new sorbicillinoid, from a marine-derived fungus Penicillium citrinum SpI080624G1f01. J. Antibiot. 2010, 63, 203-205. [CrossRef] [PubMed]

57. Simmons, L.; Kaufmann, K.; Garcia, R.; Schwär, G.; Huch, V.; Müller, R. Bendigoles D-F, bioactive sterols from the marine sponge-derived Actinomadura sp. SBMs009. Bioorg. Med. Chem. 2011, 19, 6570-6575. [CrossRef] [PubMed]

58. Igarashi, Y.; Asano, D.; Sawamura, M.; In, Y.; Ishida, T.; Imoto, M. Ulbactins F and G, polycyclic thiazoline derivatives with tumor cell migration inhibitory activity from Brevibacillus sp. Org. Lett. 2016, 18, 1658-1661. [CrossRef] [PubMed]

59. Newman, D.J.; Cragg, G.M. Natural products as sources of new drugs from 1981 to 2014. J. Nat. Prod. 2016, 79, 629-661. [CrossRef] [PubMed]

(C) 2017 by the authors. Licensee MDPI, Basel, Switzerland. This article is an open access article distributed under the terms and conditions of the Creative Commons Attribution (CC BY) license (http:/ / creativecommons.org/licenses/by/4.0/). 